\title{
EARLY TRACES OF THE BOOK OF DANIEL
}

\author{
Roger Beckwith
}

\begin{abstract}
Summary
In three intertestamental works, dating from before the time when the Book of Daniel is commonly supposed to have been written, a knowledge of the book seems to be reflected. We were formerly dependent on translations of these works, which made such an inference less certain, but we now have access to sufficient parts of the original to confirm that the translations are reliable. We also have a clearer idea now when one of the works (the Book of Watchers) was written.
\end{abstract}

There have always been those who are unpersuaded by the Maccabean dating which, since the latter part of the nineteenth century, has commonly been assigned to the Book of Daniel. Some have criticised the philosophical assumptions underlying such a dating, and some the alleged acceptability of pseudonymity as a respectable literary device in Jewish prophetic literature, while others have addressed the historical and linguistic problems which have been supposed to prove the lateness of the book. ${ }^{1}$ Since the Qumran discoveries took place, a lot of new historical and linguistic evidence bearing (directly or indirectly) on the date of Daniel has been emerging, ${ }^{2}$ and some of it has the effect of confirming apparent allusions to the book found in writings predating its supposed time of composition. Three such allusions are the subject of this article.

1 An important study of this third kind is D.J. Wiseman, T.C. Mitchell, R. Joyce, W.J. Martin and K.A. Kitchen, Notes on Some Problems in the Book of Daniel (London: Tyndale Press, 1965).

2 For an attempt to summarise this new evidence, see the section 'The ancient attitude to the Book of Daniel' in my book The Old Testament Canon of the New Testament Church, and Its Background in Early Judaism (London: SPCK; Grand Rapids: Eerdmans, 1985-86) 355-58, together with the notes on pp. 414-17. Two of the allusions to Daniel which form the subject of this article are noted in my book, but not the third. 


\section{The Book of Tobit}

The earliest of these writings, perhaps, is the Book of Tobit, very likely the oldest of the books of the Apocrypha. The direct Persian influence on this book and its familiar acquaintance with the ancient Book of Ahiqar are unique features, and the arguments used by D.C. Simpson in Charles's collection ${ }^{3}$ and by W.O.E. Oesterley in his Introduction to the Books of the Apocrypha ${ }^{4}$ for the integrity of the book and its early date, are still sound. They date it in the late third or early second century $\mathrm{BC}$, and discoveries made since have not inclined scholars to date it any later. The most recent attack on the integrity of the book, made by Frank Zimmermann in his Dropsie edition of Tobit, ${ }^{5}$ and claiming that chapters 13 and 14 must have been added after $\mathrm{AD} 70$, came less than ten years before the announcement by J.T. Milik that fragments of four Aramaic manuscripts and one Hebrew manuscript of the book had been found at Qumran, several of them extending to chapters 13 and 14.6 One or other of these two Semitic texts, probably the Aramaic one, must represent the original of the book, and now that the fragments have been published, ${ }^{7}$ we know that the editors date several of the manuscripts that include chapter 14 to about $50 \mathrm{BC}$, and one of them to about $100 \mathrm{BC}$. It is therefore not surprising that both the main recensions of the Greek translation of Tobit in the Septuagint include chapters 13 and 14. The Qumran discoveries show that the longer but less familiar of these recensions, represented by Codex Sinaiticus and the Old Latin translation, is the one closer to the original.

Now, in chapter 14 the author makes his hero, supposedly living in ancient Nineveh, at the end of his life warn his son to migrate to Media, because the prophet Nahum had foretold Nineveh's destruction, and he believed it. He goes on to say that the prophets of Israel had also foretold other important events, which would all take place: the captivity, the desolation of the land, the burning of

3 R.H. Charles, ed., The Apocrypha and Pseudepigrapha of the Old Testament (Oxford: Clarendon, 1913) vol. 1, 183-85, 194-96.

4 Oesterley, Introduction to the Books of the Apocrypha (London: SPCK, 1935) 167-69.

5 Zimmermann, The Book of Tobit (New York: Harper, 1958) 24-27.

6 Milik, 'La patrie de Tobie', Revue Biblique 73 (1966) 522-30, esp. 522.

7 In J.C. Vanderkam et al., Discoveries in the Judaean Desert XIX (Oxford: Clarendon, 1995) 1-76, esp. 57-59. The editor of Tobit here is J.A. Fitzmyer, completing the work of the late J.T. Milik. 
the temple, then the return from the exile, and the rebuilding of the temple, but not like the first,

... until the time when the time of the seasons be fulfilled; and afterwards they will return, all of them, from their captivity, and build up Jerusalem with honour, and the house of God shall be builded in her, even as the prophets of Israel spake concerning her (Tobit 14:4-5, Codex Sinaiticus, Simpson's translation).

This passage, though in a somewhat fragmentary state, is clearly represented, apparently verbatim, in one of the Aramaic fragments, $4 \mathrm{QTob}^{\mathrm{c}}$ ar, dated about $50 \mathrm{BC}$. It envisages a second more general return from exile, when Jerusalem and the temple will be built with appropriate honour, as the prophets of Israel spoke concerning them, which is to take place at 'the time when the time of the seasons ${ }^{8}$ is fulfilled'. This glorious future rebuilding of Jerusalem and its temple is probably seen by the author as foretold by Isaiah and Ezekiel respectively. But who fixed 'the time when the time of the seasons would be fulfilled' for this to happen? Could it be anyone but Daniel? It was the author of the Book of Daniel who, taking his cue no doubt from Jeremiah's now fulfilled prophecy of the seventyyear exile, to which he refers in Daniel 9:2, displays such interest in the 'times and seasons' which God's power controls (Dn. 2:21), and particularly in the times when the great events still lying in the future will occur - at the end of the three and a half times (Dn. 7:25; 12:7), of the 2,300 evenings and mornings (Dn. 8:14), of the seventy weeks (Dn. 9:24), of the 1,290 days and the 1,335 days (Dn. 12:11-12). At the end of each of these periods suffering will end and blessing will follow for God's people; and the glorious rebuilding of Jerusalem and its temple, anticipated by the author of Tobit, would certainly be such events, which could reasonably be expected to take place at such a time.

\section{The Book of Watchers}

Possibly as old as Tobit, or even older, is the first part of the Book of Enoch, the Book of Watchers, occupying chapters 1-36 of the whole. 1 Enoch is a composite work, consisting of five distinct parts, four of which have been found at Qumran in the original Aramaic, together with other related material. The Qumran material is of course

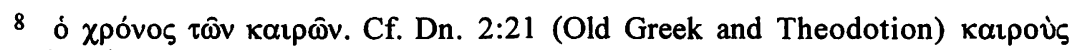
кai xpóvous. 
fragmentary, but it is sufficiently extensive to show that the complete Ethiopic translation, on which in the past we had to rely almost entirely, is substantially reliable; though the third part, the Astronomical Book, is much condensed in the Ethiopic version, and the second part, the Book of Parables, must have been added to the work by editors outside Qumran, possibly to replace the Book of Giants, which has been found at Qumran but does not occur in the Ethiopic text. The Aramaic manuscripts were carefully edited by Milik. ${ }^{9}$ Milik reckons the Book of Watchers one of the earliest parts of 1 Enoch, and he dates the oldest manuscript of it some time in the first half of the second century $\mathrm{BC},{ }^{10}$ which suggests that the actual composition of the Book of Watchers could well go back to the third century BC.

The Book of Watchers has a remarkably close relationship with the Book of Daniel. The term 'watcher' or 'wakeful one' (Aramaic ע) is used for an angel in no other book of the Old Testament except Daniel (Dn. 4:13, 17, 23), but it is common in the Book of Watchers (1 Enoch 10:7, 9; 12:2, 3; 13:10;14:1, 3; 15:2, 9; 16:1, 2; 22:6 Aramaic), where, as in Daniel, it is linked with the term 'holy one' (1 Enoch 12:2; 22:6 Aramaic). The Book of Daniel is also the only Old Testament book to give angels individual names, the names being Gabriel (Dn. 8:16; 9:21) and Michael (Dn. 10:13, 21; 12:1): the same two names are given to angels in the Book of Watchers (1 Enoch 9:1; 20:5, 7), and many angels are there given similar names, likewise ending in (including Raphael, also found in Tobit). ${ }^{11}$ Still more striking are the links between the vision of God in Daniel 7:9-10 and that in 1 Enoch 14:18-22, though in the latter passage the chariot vision of Ezekiel (Ezk. 1 and 10), where the divine throne is of crystal and is carried by the cherubim, is also drawn upon. This passage of Enoch is found in the Qumran Aramaic in three little fragments, each containing only one or two words, ${ }^{12}$ sufficient to show that the Aramaic wording is not identical with that of Daniel, but that the meaning is the same. In Charles's translation of the Ethiopic, the passage runs:

9 J.T. Milik, The Books of Enoch: Aramaic Fragments of Qumran Cave 4 (Oxford: Clarendon, 1976).

10 Milik, The Books of Enoch, 22-23.

11 Tobit 3:17, 5:4, 12:15, etc. In Tobit 12:15 he is said to be one of seven archangels, as in the Book of Watchers (1 Enoch 20).

12 This is in the manuscript $4 Q \mathrm{QEn}^{\mathrm{c}} \mathrm{I}$ vii, printed in Milik's edition on p. 199.

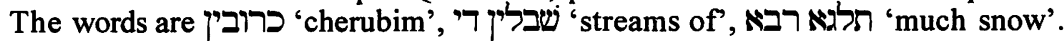
The MS is dated by Milik in the last third of the first century BC (p. 178). 
And I looked and saw therein a lofty throne: its appearance was as crystal, and the wheels thereof as the shining sun, and there was the vision of cherubim. And from underneath the throne came streams of flaming fire so that I could not look thereon. And the Great Glory sat thereon, and his raiment shone more brightly than the sun and was whiter than any snow. None of the angels could enter and could behold his face by reason of the magnificence and glory, and no flesh could behold him. The flaming fire was round about him, and a great fire stood before him, and none around could draw nigh him: ten thousand times ten thousand stood before him, yet he needed no counsellor.

Now compare this with Daniel 7:9-10:

I beheld till thrones were placed, and one that was ancient of days did sit: his raiment was white as snow, and the hair of his head like pure wool; his throne was fiery flames, and the wheels thereof burning fire. A fiery stream issued and came forth from before him: thousand thousands ministered unto him, and ten thousand times ten thousand stood before him. The judgment was set, and the books were opened.

The phrases in italics are obviously connected, and show dependence on one side or the other. At the same time, the anthropomorphisms of Daniel are avoided in Enoch: God is not ancient of days, and does not have hair like pure wool, nor could anyone draw nigh to minister to him. And Enoch is careful to add the apologetic observation 'yet he needed no counsellor'. These rather sophisticated features suggest that the dependence is on the side of Enoch. The fact that Enoch draws also upon Ezekiel suggests the same thing. And when one considers the general literary and spiritual quality of Daniel, as compared with Enoch, the widespread assumption that Daniel took Enoch for a model is seen to be implausible. Rather, Enoch took Daniel for a model, and the whole pseudonymous apocalyptic literature which followed in the wake of Enoch presupposed the existence of Daniel-a work of far greater worth, and a contender for a place in the recognised Jewish canon of Scripture. ${ }^{13}$

13 On the question when Daniel was finally accepted into the canon, see note 16 below. Enoch was a standard text at Qumran, and was probably part of an interpretative appendix to the national canon, recognised by the Qumran (Essene?) school of thought, though not regarded by them as actually Scripture or quoted in their literature with the distinctive formulas for Scripture (see my book The Old Testament Canon of the New Testament Church, 74-75, 115-18, $358-66$, to which, with the publication of 4QMMT, an important new piece of evidence has been added.) There is another parallel in Enoch to the vision in Daniel 7, this time in the Book of Giants (4Q530). The Book of Giants is one of the latest parts of Enoch: it deals not with the watchers but with their offspring, now individualised and named, and no MS of it is older than the first century BC. It is not one of the alleged writings of Enoch known to the author of Jubilees (Jub. 4:17-24). Very likely, the vision here depends as much on that 


\section{Ecclesiasticus}

A book that can be dated with some exactness is Ecclesiasticus, the Wisdom of the son of Sirach. From the combined evidence of the Greek translator's precise prologue and the author's eye-witness account of the high priest Simon the Just, it is generally agreed that it was written about $180 \mathrm{BC} .{ }^{14}$ The original language was Hebrew, and much of the Hebrew text has now been recovered, particularly from the Cairo Geniza and Masada.

In the first seventeen verses of chapter 36 , Ben Sira prays to the Lord to vindicate and restore his people and to judge the nations that oppress them. The prayer appears to arise out of the concluding verses of chapter 35, and it is found in the Greek and Syriac as well as in the Hebrew, so the suggestion that it is a later addition is gratuitous. Nor is this the only occasion when the author breaks into prayer: he has done it previously in 22:27-23:6. And the severe attitude of the prayer to hostile foreign nations is quite consistent with 50:25-26.

The prayer asks, among other things, for prophecy to be fulfilled, and in verse 8 the Hebrew text says

החיש קץ ופקוד מוער

Hasten 'the end' and ordain 'the appointed time'.

There had been an earlier 'appointed time' (מוער), referred to in Psalm 102:13. This was the time appointed by the Lord through Jeremiah for Zion to be rebuilt, after the seveniy years of the

in the Book of Watchers as it does on that in Daniel 7, and, like the former, it avoids the anthropomorphic features of Daniel 7. It also greatly reduces the number of bystanders, whose presence the author perhaps thinks unnecessary. But it would be difficult to agree with L.T. Stuckenbruck that this late and weak passage is the original on which Daniel 7 depends, as he argues in his essay 'The Throne-Theophany of the Book of Giants: Some New Light on the Background of Daniel 7', in S.E. Porter and C.A. Evans, eds., The Scrolls and the Scriptures (JSPS 26; Sheffield: Sheffield Academic, 1997) 211-20.

14 However, the contention of E.B. Pusey (Lectures on Daniel the Prophet [3rd edn; Oxford: Parker, 1876] lecture 6) and J.H.A. Hart (Ecclesiasticus: The Greek Text of Codex 248 [Cambridge: CUP, 1909] 249-66), that Ecclesiasticus and its prologue were written about a hundred years earlier than the usual dates, has never actually been disproved, only ignored. If this were the case, Ben Sira's reference would be to the first high priest Simon, not the second, and the translator's reference would be to the first Ptolemy Euergetes, not the second. Because of the contents of the book and the translator's prologue, there would be far-reaching consequences for the history of the canon and of the Septuagint; and a date in the fourth century BC rather than the third might become probable for the composition of Tobit. 
Babylonian exile (Je. 25:11-12; 29:10; cf. 2 Ch. 36:21-22; Ezr. 1:1; Zc. $1: 12 ; 7: 5)$, but when that time had almost been reached, as Daniel afterwards perceived it had been (Dn. 9:2), he foresaw another

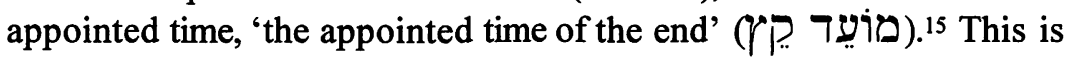
in Daniel 8:19, which seems from the context to refer to the persecution of Antiochus Epiphanes, brought to a conclusion by his death (vv. 23-25). This future 'appointed time' (מוֹעֵך) is also referred to in Daniel 11:27, 29, 35, and Daniel 11:27, 35 refer likewise to 'the end' (ק) or 'the time of the end' (עית קי) a phrase used in a number of other verses-in Daniel 8:17, 11:40, 12:4, 9 and in all these places the reference seems to be primarily to Antiochus Epiphanes, though not perhaps excluding some later persecutor foreshadowed by Antiochus. This being so, the prayer of Ben Sira would most naturally belong to the period before Antiochus Epiphanes and his downfall, when the appointed time of the end had not yet been reached; and, as Ben Sira wrote about $180 \mathrm{BC}$, this is indeed when the prayer was made. But it was made with full knowledge of the prophecies contained in Daniel 8 or 11-12, and asks explicitly that they may soon be fulfilled. 16

In these three ancient works, therefore, Tobit, the Book of Watchers and Ecclesiasticus, all dating from before $167 \mathrm{BC}$, we seem to find a direct knowledge of the Book of Daniel. It is not just a knowledge of the first six chapters of narrative, which some critics are willing to concede may be older than the rest (the apparent unity of the book notwithstanding), but more particularly a knowledge of the last six chapters of visions; and it extends to the Hebrew as well as the Aramaic part of the book. The author of Tobit seems to know Daniel 2 and some if not all of the chapters 7, 8, 9 and 12. The author of the Book of Watchers seems to know Daniel 4, 7, 8 or 9, and 10 or 12, if not all of these. The author of Ecclesiasticus seems to know Daniel 8 or 11-12, and probably both.

15 'The appointed time of the end' is not the only possible translation, but the parallel phrase 'the time of the end' (Y) ( Dn. 8:17;11:35, 40;12:4, 9-favours it.

16 Since Ben Sira evidently knew the Book of Daniel, it is the more interesting that Daniel and his companions do not feature in his catalogue of famous men (Ecclus. 44-49). Mordecai and Esther do not feature there either. The probable reason is that Daniel and Esther had not yet been definitely accepted as canonical, although moving towards it. At the end of Ecclus. 48, as Pusey long ago pointed out (loc. cit.), Ben Sira sums up his list of the famous men of Scripture by returning to the beginning of biblical history, before passing on to the non-biblical figure of Simon the high priest in chapter 49. 
If it is the case that any hypothesis is to be preferred to the hypothesis that Daniel foretold the persecution and death of Antiochus Epiphanes in advance, then, of course, these ancient witnesses must either be dated improbably late or the integrity of their writings must be challenged; but if the possibility of predictive prophecy is granted, then it is clear that the Book of Daniel, in substantially its present form, was already known and studied (even if it had not yet attained full canonicity) in the period from about 250 to $180 \mathrm{BC}$. 